\title{
Recurrence and equilibrium of temporal ponds of a mountain range in Central Spain
}

\author{
By Antonio G.-Valdecasas, Alberto Fernandez Lop and Ana Isabel \\ CAMACHO
}

With 4 tables in the text

\begin{abstract}
This paper is an exploration of the model of insular biogeography applicated to a set of temporal ponds in a mountain range. Both hypothesis, ponds as "habitat-island" and mountain range as "continental-island" are considered. Fauna renovation and renovation rate are calculated for water mites.

It is accepted traditionally in Ecology, that the relations between species and area could be synthetize as the following expression: $S=c A^{z}$, where $c$ and $\mathrm{z}$ are two constants, $\mathrm{S}$ is the number of species and $\mathrm{A}$ the area. This relation was first suggested by ArrHenius (1921) although not in an explicit way, and has suffered since then critics and supports frem different authors (see ConNORs \& McCoy, 1979 for a recent review).

Preston (1962) and MacArthur \& W Wilson $(1963,1967)$ suggested independently that this relation could arise from an species equilibrium. This equilibrium could be the result of two opposite process: migrations and extinctions. Developped initially for the island biota, the application of the model was subsequently extended to continental habitats that resemble islands. The model, as MACArTHUR \& Wirson developped it mathematically, has been used in so different situations as "paramo-island" (Vuilluimier, 1970), "cave-islands" (Vuilluimier, 1973; Culver et al., 1973), “riveris-lands" SEPKosKr et al. (1974), etc. Connors \& McCoy (1979) give a list of 100 papers and this is only a fraction of the bibliography today available on this theory. A recent discussion can be found in WILLIAMSON (1981).

Temporal ponds as a subject for the model of insular biogeography has been considered only by HuBBard (1973). In the present paper we explore the appropiateness of the model of insular biogeography to small volumes of water in a mountain range in Central Spain.
\end{abstract}

\section{Material and methods}

\section{Study area}

The sierra del Guadarrama is a small mountain range to the north of Madrid. Its area at the $1,000 \mathrm{~m}$ altitude level is $5,800 \mathrm{~km}^{2}$. We have divided the area in squares of 
$5 \mathrm{~km}$ side and we have searched for a pond in each square. Forty three temporal and permanent ponds were found and samples were taken in two occasions. The last period of sampling was realized in August, in order to verify if the ponds were temporal. A detailed description of each pond and their location can be found in Camacho et al. (1982).

\section{Sampling method}

Each pond was sampled in two different ways in each occasion. First, we realized a standard sweep of $1.5 \mathrm{~m}$. Second, every physical discontinuity was sampled with a net, with a triangular mouth, $20 \mathrm{~cm}$ side, $50 \mathrm{~cm}$ long and $180 \mathrm{~nm}$ mesh. Samples were fixed with formalin $5 \%$ at the sampling point and sorted posteriorly at the laboratory. In every pond we have measured: altitude, maximum depth, pond area, water and air temperature, $\mathrm{pH}$, hardness, alcalinity and qualitative observations on the substrate and companion macrophytes. The methodology of physico-chemical analyses is described in G.VALDECASAS (1981).

\section{Identification and mathematical procedure}

Taxa have been identified to the lower level using general monographies, as is detailed in Camacho et al. (1982). We would like to thank the help of E. Ortrz and D. G. DEL JALON with copepods and caddis flies respectively. The list of taxa can be obtained from the authors on request.

Linear and stepwise regression were done with the BMDP package (Dixon, 1979).

\section{Results}

Table 1 contains the data for the 38 of 43 ponds where invertebrates were found. It includes if the pond is temporal or permanent, the area in $\mathrm{m}^{2}$ and number of species of Hemiptera, Coleoptera, Odonata, Hydracarina, Copepoda and the Total found in each pond. These data were the base for the linear regression, taking the area $(\mathrm{A})$ as the independent variable and the number of species $(S)$ of every group as the dependent one. Linear regression was done using two models: the potential, via its logarithmic transformation and the exponential (see Connors \& McCoy, 1979).

Table $2 \mathrm{a}$ includes the regression equations obtained. Table $2 \mathrm{~b}$ shows the values of the correlation coefficient for each of the relations studied in both models.

Only the copepods shows a significant correlation, $r=0.49(P<0.005)$ with area, although a weak one as is reflected from the low value of $r$.

Two aspects are important to stablish the value of $\mathrm{z}$ in the cases studied. As Connors \& McCox (1979) have pointed out there are no a priori reasons to prefer a potential or exponential species/area relationship. Even more, the potential relation could be approximate in an iterative way (SEPKowsKu et al., 1974) or by logarithmic transformation. We have examined both models, the potential through logarithmic transformation. Two criteria can be followed to decide which of both models fit better to the data (Connors \& $\mathrm{McCor}$, op. 
Table 2 a. Area/species relationship.

\begin{tabular}{lll}
\hline & \multicolumn{2}{c}{ Model } \\
\cline { 2 - 3 } & Potential & Exponential \\
\hline Odonata & $\mathrm{S}=1.11 \cdot \mathrm{A}^{0.089}$ & $\mathrm{~S}=0.335 \mathrm{~A}+0.223$ \\
Hemiptera & $\mathrm{S}=4.41 \cdot \mathrm{A}^{-0.105}$ & $\mathrm{~S}=-0.664 \mathrm{~A}+3.72$ \\
Copepoda & $\mathrm{S}=1.51 \cdot \mathrm{A}^{0.259}$ & $\mathrm{~S}=1.88 \mathrm{~A}+0.624$ \\
Coleoptera & $\mathrm{S}=7.56 \cdot \mathrm{A}^{0.079}$ & $\mathrm{~S}=-1.087 \mathrm{~A}+6.13$ \\
Hydracarina & $\mathrm{S}=1.78 \cdot \mathrm{A}^{0.079}$ & $\mathrm{~S}=0.897 \mathrm{~A}+0.576$ \\
Total & $\mathrm{S}=8.29 \cdot \mathrm{A}^{0.058}$ & $\mathrm{~S}=0.947 \mathrm{~A}+10.48$ \\
\hline
\end{tabular}

Table 2 b. Correlation coefficient for area/species relationship.

\begin{tabular}{lll}
\hline & \multicolumn{2}{c}{ Model } \\
\cline { 2 - 3 } & Potential & Exponential \\
\hline Copepoda & 0.4865 & 0.4678 \\
Hemiptera & 0.1974 & 0.1714 \\
Odonata & 0.2326 & 0.1962 \\
Coleoptera & 0.2594 & 0.2207 \\
Hydracarina & 0.1477 & 0.2162 \\
Total & 0.1249 & 0.0923 \\
\hline
\end{tabular}

We have explored if any of the environmental variables could be a better predictor of the number of species in the pond. Several stepwise regressions were done for each and the total group of species (dependent variables) and the $\mathrm{pH}$, alcalinity, hardness, area, altitude and maximum depth of each pond (independent varaibles). No significant relationship were obtained except for the total number of species with $\mathrm{pH}\left(\mathrm{R}^{2}=0.31\right)$ and depth $\left.\mathrm{R}^{2}=0.20\right)$.

These weak relations made us to look for an alternative. From the idea of pond as "island-habitat" we changed to the whole mountain range as a "continental-island". To test this possibility we have limited to water mites, because this is one of the groups best known in this area. We have used the relation given by PRESTON (1962) for two areas: $z=\log \left(N_{1} / N_{2}\right) / \log \left(A_{1} / A_{2}\right)$. Taking in account that exist three previous records of the lentic water mites in this area, one in 1918 (VIETS, 1930), another in 1978 (G.-VALDECASAS, 1981) and the last one in 1982 (САмАСНO, 1982) and three records for lotic water mites: in 1918 (VieTs, 1930), 1935 (LundBlad, 1956) and 1978 (G.-VAldeCASAS, 1981), we have calculated the renovation $(R)$ and the renovation rate $\left(T_{R}\right)$ (Аввот, 1980) for the fauna in these two periods, with the following algorithm: $R=E+I / 1 / 2$ $\mathrm{S}_{1}+\mathrm{S}_{2}$ and $\mathrm{T}_{\mathrm{R}}=\mathrm{R} / \mathrm{C}$ where:
$\mathrm{R}$ is the fauna renovation,
$\mathrm{E}$ is the extinction between two periods,
I is the immigration between two periods, 
$S_{1}$ is the number of species in census 1 ,

$\mathrm{S}_{2}$ is the number of species in census 2,

$\mathrm{T}_{\mathrm{R}}$ is the renovation rate, and

C is the interval between censuses, in years.

[The other area used has been the Pirinees, and the fauna list has been taken from VieTs, in ILLIES (1978).]

Table 3 shows the values of $\mathrm{z}$ for lentic, lotic and total water mite fauna. Table 4 gives the values of renovation and renovation rate for water mites lotic and lentic.

\section{Discussion and conclusion}

The relation area/species and the distribution species/individuals assuming a log-normal distribution of the later, lead to a theoretical value of the constant $\mathrm{z}$ in the equation $\mathrm{S}=\mathrm{cA}^{\mathrm{z}}$ of $\mathrm{z}=0.263$ (Preston, 1962). Higher values are taken as evidence of more strict isolation and lower values appear as we approach a continental situation (McArThur \& WILSON, 1967). The constant $\mathrm{c}$ changes from taxon to taxon and in different parts of the world, and there is not an unique interpretation of it (see GouLD, 1979 for a possible way of interpreting c). A second aspect refers to the model of regression employed. As SoKal \& RoHLF (1981) point out, of the two models of regression, model I, where the interval of the independent variable are fixed by the investigator, is adequate for experimental situations. Model II, where both variables can take arbitrary

Table 3. Area/species relationship for the water mites of sierra del Guadarrama and the Pirinees.

\begin{tabular}{|c|c|c|c|}
\hline Sierra del Guadarrama: & $\mathrm{A}_{1}=5888 \mathrm{~km}^{2}$ & Number species & $\begin{array}{l}N_{1} \text { (Lenthic) }=51 \\
N_{2} \text { (Lotic) }=61\end{array}$ \\
\hline Pirinees: & $\mathrm{A}_{2}=18.884 \mathrm{~km}^{2}$ & Number species & $\begin{array}{l}N_{1} \text { (Lenthic) }=58 \\
N_{2} \text { (Lotic) }=92\end{array}$ \\
\hline . & $\begin{array}{l}Z \text { (Lenthic) }=0.1 \\
Z \text { (Lotic) }=0.356\end{array}$ & & \\
\hline
\end{tabular}

Table 4. Renovation and renovation rate in water mites.

\begin{tabular}{|c|c|c|c|c|}
\hline \multicolumn{5}{|c|}{ Renovation lenthic Hydracarina } \\
\hline$S_{1}$ (1918): 29 & & $S_{1}-----S_{2}$ & $S_{2}-----S_{3}$ & $S_{1}-----S_{3}$ \\
\hline$S_{2}(1978): 15$ & $\mathrm{R}$ & 1.59 & 0.92 & 1.49 \\
\hline$S_{3}(1982): 26$ & $\mathrm{~T}_{\mathrm{R}}$ & 0.09 & 0.31 & 0.02 \\
\hline \multicolumn{5}{|c|}{ Renovation in lotic Hydracarina } \\
\hline$S_{1}(1918): 21$ & & $S_{1}-----S_{2}$ & $S_{2}-----S_{3}$ & $S_{1}-----S_{3}$ \\
\hline$S_{2}(1935): 20$ & $\mathrm{R}$ & 1.50 & 1.03 & 1.40 \\
\hline$S_{3}(1978): 41$ & $\mathrm{~T}_{\mathrm{R}}$ & 0.08 & 0.02 & 0.02 \\
\hline
\end{tabular}


values, are more adequate to situations as the one we are studying, because neither the number of species nor the pond area can be fixed by the investigator. The traditional method to fit a regression line under model II is that of Barnett (Simpson et al., 1960; Sokal \& Rohlf, 1969), method that has been heavily critizied by RICKER (1973) and others. Several alternatives have been proposed by Ricker and other authors (SOKAL \& RoHLF, 1981) but they do not seem satisfactory. So there is not a commonly accepted methodology to fit curves under model II, and there could be important differences fitting with the two models (see LAW \& Archie, 1981). Notwithstanding, we have accepted an intermediate solution, because as SoKaL \& RoHLF have written (1981, page 549): "The subject of model II is one on which research and controversy are continuing and definitive recommendation are difficult to make. Much will depend on the intentions of the investigator. If the regression line is being fitted mainly for purposes of prediction, the simple linear regression techniques (the model I) are generally applied". So we think that the values of $\mathrm{z}$ found are not necessarily the artifact of mathematical procedure.

Empirical value of $\mathrm{z}$ are between $\mathrm{z}=0.24$ and $\mathrm{z}=0.36$ (MAY, 1975, 1981) taking in account sampling error. Nevertheless there are much higher values reported in the literature (e.g. Culver et al., 1973).

In our case, only the potential model with copepods fits within the limits predicted as typically insular by the theory. It is difficult with out data, to evaluate properly the real meaning of it. Of the four remaining groups analyzed, three are order of insects that leave the pond at a certain date of their development. The fourth group, the Hydracarina, leaves the pond too, as parasites of insect in their larval state. The permanence of copepods as a phase of resistance between the successive dry stages, is perhaps the only biological data that distinguish copepods from the rest. This "continuity" could derive in a "equilibrate" relation between the different species of copepods living in the area, situation not so easy to reach with the intermittent phases of invasion-dispersion of the other groups. This is why some authors (e.g. WIGgins et al., 1980) have considered that temporal ponds could not be appropiate examples of the model of insular biogeography, because their "life-span" is shorter than the time needed to produce that equilibrium.

The alternative hypothesis of sierra del Guadarrama as a "mountainisland" confront similar problems of interpretation. The values of $\mathrm{z}$ for lenthic and lotic water mites are very different: $z=0.1$ lenthic; and $z=0.316$ lotic. Although the value of $z$ for both sets together, $z=0.25$, is between the limit predicted by the model, it does not seem appropiate to use it just because both groups are ecologically independent. It seems that both groups react in a different way to a "mountain situation". The $\mathrm{z}$ high value in lotic water mites reflecting certain isolation, could be assimilated to the zonation found in running waters between different reaches of the fluvial systems, keeping bio- 
cenotic identity despite their physic continuity. For lenthic water mites these zonation does not exist, and it seems that the mountain range is not high enough to constitute an island.

The values of renovation and renovation rate show certain regularities. Although Diamond \& May (1977) favour regular censuses and ReEd (1980) proposes periods of ten year interval, Аввот (1980) claims to the contrary, arguing that the renovation rhythm could be detected independently from the time elapsed. Our data tend to support Аввот views, but are not enough conclusive to go beyond to confirm this regularity. It would be desirable to check this regularities with other groups.

\section{Summary}

In this paper, we explore the application of the model of insular biogeography to a set of temporal ponds in a mountain range. Two different models of species/area relationships, the exponential and the potential are applied to 43 temporal and permanent ponds, and Copepoda, Hydracarina, Odonata, Coleoptera, Hemiptera and the total number of species in each pond. Only the copepods show a value of $z$ between the limit predicted by the model. The consideration of the mountain range as a continental island, shows certain correlation with traditional zonation of fluvial systems. Censuses of water mites along this century have allow us the detection of certain regularities in renovation and renovation rate of this fauna in the mountain range.

\section{Résumé}

Dans ce travail, on applique le modèle de biogeographie insulaire aux mares temporaires d'une montagne du centre de l'Espagne. Deux modèles differents de la relation superficie/espèces: le modèle potenciel et l'exponenciel, ont été appliqués à 43 mares temporaires et permanentes et aux groupes suivants d'invertébrés aquatiques: Copèpodes, Odonates, Coleoptères, Hydracariens, et Hemiptères. Uniquement les Copèpodes montrèrent une valeur de $\mathrm{z}$ comprise entre les limites prédit par le modèle. La consideration de la montagne comme une île continentale montre une certaine corrèlation avec la zonation tradicionelle des systèmes fluviaux. Les recensements des Hydracariens tout le long de ce siècle ont permis de detecter certaines règularitès en renouvellement et des taux de renouvellement de cette faune dans la montagne.

\section{Acknowledgements}

We thank ANTONIo CoRCuERA for his help during sampling trips.

\section{References}

Аввот, I. \& BLACK, R. (1980): Change in species composition of flora of islets near Perth, Western Australia. - J. Biogeo. 7: 399-410.

Самасно, А. I. (1982): El medio léntico temporal en la sierra del Guadarrama, con especial referencia a la fauna de hidracnelas. - Tesina de Licenciatura. Universidad Autónoma de Madrid, 1-315.

4 Archiv f. Hydrobiologie, Bd, 102 
Camacho, A. I., Lop, A. F. \& G.-Valdecasas, A. (1982): Contribución al conocimiento delas aguas estancadas de la sierra del Guadarrama. - Act. I Congr. Nac. Protec. Nat. y Medio Hum. (in press).

Connors, E. F. \& McCoy, E. D. (1979): The statistics and biology of the species/area relationship. - Am. Nat. 113: 791-833.

Culver, D., Holsinger, J. R. \& Bargody, R. (1973): Towards a predictive cave biogeography: the Greenbriar Valley as a case study. - Evolution 27: 689-695.

DiAmond, J. \& MAY, R. M. (1977): Species turnover rates on islands: dependence on census intervals. - Science 1977: 266-270.

Drxon, R. (1979): Biomedical Computer Programs. - University California Press, Berkeley.

G.-VALDECASAS, A. (1981): Las hidracnelas de la sierra del Guadarrama: - Taxonomía, distribución y ecología. - Tesis doctoral. Universidad Complutense de Madrid, $1-532$.

GouLD, S. J. (1979): An allometric interpretation of species-area curves: the meaning of the coefficient. - Am. Nat. 114: 335-343.

HuBbard, M. D. (1973): Experimental insular biogeography: ponds as islands. - Florida Scientist 36: 132-141.

Lundblad, O. (1956): Zur Kenntnis süd- und mittelamerikanischer Hydrachnellen. Ark. Zool. 10: 1-306.

MACArTHUR, R. H. \& WiIsON, E. O. (1963): An equilibrium theory of insular zoogeography. - Evolutien 17: 373-387.

- - (1967): The theory of island biogeography. - Princeton University Press, Princeton.

MaY, R. M. (1975): Pattern of species abundance and diversity. - In: Ecology and Evolution of Communities, 81-120 (ed. M. L. Cody \& J. M. Diamond). Belknap Press of Harvard University Press, Cambridge, MA.

- (1981): Pattern in multi-species communities. - In: R. M. MAY (ed.) Theoretical Ecology: 197-227. - Blackwell Scientific Publication, Oxford.

Preston, F. W. (1962): The canonical distribution of commoness and rarity. - Ecology 43: $185-215 ; 410-432$.

ReED, T. M. (1980): Turnover frequency in island bird. - J. Biogeo. 7: 329-335.

RICKER, W. E. (1973): Linear regression in fishery research. - J. Fish. Res. Board. Can. 30: 409-434.

SEPROwski, J. J. \& Rex, M. A. (1974): Distribution of freshwater mussels: coastal rivers as biogeographic islands. - Syst. Zool. 23: 165-188.

Simpson, G. G., RoE, A. \& Lewontri, R. C. (1960): Quantitative Zoology. - Harcout, Brace and Co., New York. 1-440.

SokaI, R. R. \& RohlF, F. J. $(1969,1981):$ Biometry. $1^{\text {rst }} \& 2^{\text {nd }}$ edition. - W.H. Freeman and Company. San Francisco, 776, 859.

VIETS, K. (1930): Zur Kenntnis der Hydracarina-Fauna Spaniens. - Arch. Hydrobiol. 21: $175-240 ; 359-446$.

VIETs, K. O. (1978): Hydracarina. - In: J. ILuEs (ed.). Limnofauna Europaea, $2^{\text {nd }}$ ed. Gustav Fischer, Stuttgart.

Vuillumier, F. (1970): Insular biogeography in continental regions. I. The northern Andes of South America. - Amer. Nat. 104: 373-388.

- (1973): Insular biogeography in continental regions. II. Cave faunas from Tessin, southern Switzerland. - Syst. Zool. 22: 64-76.

Wituiamson, M. (1981): Island Populations. 1-286. - Oxford University Press, Oxford. 
Wiggins, G. B., Mackay \& SMITH, I. M. (1980): Evolutionary and ecological strategies of animals in annual temporary pools. - Arch. Hydrobiol. (Suppl.) 58: 97-200.

The addresses of the authors:

Antonio G.-Valdecasas and Arberto Fernandez Lop, Museo Nacional Ciencias Naturales, Castellana 80, Madrid, 6, Spain.

Ana Isabel Camacho, Dept. Zoología, C-XV, Fac. Ciencias, Universidad Autonoma de Madrid, Madrid, 34, Spain. 